\title{
Astringency of Bovine Milk Whey Protein
}

\author{
H. Sano, ${ }^{1,2}$ T. Egashira, ${ }^{1,2}$ Y. Kinekawa, ${ }^{2}$ and N. Kitabatake ${ }^{1}$ \\ ${ }^{1}$ Division of Food Science and Biotechnology, Graduate School of Agriculture, \\ Kyoto University, Uji, Kyoto 611-0011, Japan \\ ${ }^{2}$ Research \& Development Department, Daiichi-Kasei Co., Ltd., 7-1, \\ Okanonishi-cho, Kawata, Yamashina-ku, Kyoto 607-8323, Japan
}

\begin{abstract}
Whey protein solutions at $\mathrm{pH} 3.5$ elicited an astringent taste sensation. The astringency of whey protein isolate (WPI), the process whey protein (PWP) that was prepared by heating WPI at $\mathrm{pH} 7.0$, and the process whey protein prepared at $\mathrm{pH} 3.5$ (aPWP) were adjusted to $\mathrm{pH}$ 3.5 and evaluated by 2 sensory analyses (the threshold method and the scalar scoring method) and an instrumental analysis (taste sensor method). The taste-stimulating effects of bovine and porcine gelatin were also evaluated. The threshold value of astringency of WPI, PWP, and aPWP was $1.5,1.0$, and $0.7 \mathrm{mg} / \mathrm{mL}$, respectively, whereas the gelatins did not give definite astringency. It was confirmed by the scalar scoring method that the astringency of these proteins increased with the increase in protein concentration, and these proteins elicited strong astringency at $10 \mathrm{mg} / \mathrm{mL}$ under acidic conditions. On the other hand, the astringency was not elicited at $\mathrm{pH} 3.5$ by 2 types of gelatin. A taste sensor gave specific values for whey proteins at $\mathrm{pH} 3.5$, which corresponded well to those obtained by the sensory analysis. Elicitation of astringency induced by whey protein under acidic conditions would be caused by aggregation and precipitation of protein molecules in the mouth.
\end{abstract}

(Key words: astringency, milk whey protein, process whey protein, acidic condition)

Abbreviation key: CPA = change of membrane potential caused by adsorption, $\mathbf{a P W P}=$ acidic process whey protein, $\mathbf{P W P}=$ process whey protein, $\mathbf{W P I}=$ whey protein isolate.

\section{INTRODUCTION}

Functional properties, including gelation, emulsion, and water-holding capacity, are requisite to food ingredient protein for food processing. Bovine milk whey protein produced as a by-product from cheese and butter manu-

Received October 24, 2004.

Accepted April 4, 2005.

Corresponding author: Naofumi Kitabatake; e-mail: kitabatake @kais.kyoto-u.ac.jp. facturing is used for food processing and as an additive for nutritional fortification (Mulvihill, 1992). Whey protein shows various useful functions for food processing and has high nutritional value. It was reported that whey protein interacts with the flavor compounds (Hansen and Heinis, 1992), whereas there is no report on the taste of the purified whey protein. It is known that protein including whey protein elicits no taste stimulation, except for some specific proteins found in the fruits of tropical plants (Kaneko and Kitabatake, 2001). In this study, we show that the astringent taste stimulation is elicited by milk whey proteins when the protein solution is acidic.

Acid $\mathrm{pH}$ induces a sour taste. There are many acidic foods, including fruit jellies, lactic drinks, fermented foods, and others. The sour taste of acidic foods and beverages whets some appetites and gives refreshment, particularly sour beverages which are acceptable to most people in the world. If such beverages contain protein, these not only supply a favorable taste, but also nutritious effects.

We have studied the functional properties of whey protein, and we developed process whey protein (PWP) that is prepared by heating whey protein under salt-free conditions. Process whey protein has superior functions and nutrition to whey protein isolate (WPI), including solubility at acid $\mathrm{pH}$ and high ionic strength of the medium, and is widely used as a food ingredient (Kinekawa and Kitabatake, 1995; Kitabatake and Kinekawa, 1998). Process whey protein gives cold gelation in the presence of salt (Kitabatake et al., 1996) and it is known that whey protein can give acid-induced cold gelation (Alting et al., 2004). Process whey protein has much better digestibility and higher nutritional value than WPI, as demonstrated by in vitro and in vivo experiments (Kitabatake and Kinekawa, 1998). If whey protein including PWP and other nutritious protein materials can be used for acidic beverages, a novel type of beverage providing physical and physiological functions could be developed. It is important to clarify the taste of whey proteins to widen the usage of whey proteins in foods and beverages. We demonstrate the astringent taste of whey proteins elicited at the acid $\mathrm{pH}$ in this study, using 2 sensory analyses, the threshold method and scalar scoring 
method, to evaluate the astringency of whey proteins of low and high protein concentration, respectively. To evaluate the astringency of whey protein, we also introduced an instrumental analysis using a taste sensor.

\section{MATERIALS AND METHODS}

\section{Materials}

Whey protein isolate containing $95 \%$ protein (dry base, Kjeldahl method), $3 \%$ ash (gravimetric method, $550^{\circ} \mathrm{C}$ ), $1 \%$ lactose (HPLC), $1 \%$ crude fat (extraction method), and $5 \%$ moisture (gravimetric method, $105^{\circ} \mathrm{C}$ ) was supplied from Daiichi Kasei Co., Ltd., (Daiichi-Lacto, Kyoto, Japan). The WPI was dialyzed against 10 -fold of distilled water at $4^{\circ} \mathrm{C}$ for $3 \mathrm{~h}$. Distilled water was changed 8 times. Process whey protein was prepared according to the previous report (Kinekawa and Kitabatake, 1995). Whey protein isolate solution was adjusted $\mathrm{pH}$ to 7.0 or 3.5 with $2.0 \mathrm{M} \mathrm{HCl}$ or $\mathrm{NaOH}$. The final protein concentration was adjusted to $50 \mathrm{mg} / \mathrm{mL}$. The protein solution was heated at $90^{\circ} \mathrm{C}$ for $30 \mathrm{~min}$. Process whey protein prepared by heating at $\mathrm{pH} 3.5$ is referred to as acidic process whey protein (aPWP). Gelatin from bovine skin (Type B, gel strength $~ 225$ Bloom) and gelatin from porcine skin (Type A, gel strength $~ 300$ Bloom) were purchased from Sigma-Aldrich Co., (St. Louis, MO). Both gelatins were dissolved in distilled water to $5.0 \%$ (wt/ vol). Tannic acid was purchased from Wako Pure Chemical Industries, Ltd. (Osaka, Japan). All other reagents used were of guaranteed grade except tannic acid (practical grade).

\section{Determination of Protein Concentration}

Protein concentration of whey proteins, dissolved in $20 \mathrm{~m} M$ sodium phosphate buffer, $\mathrm{pH} 7.5$, was measured from absorbance at $280 \mathrm{~nm}$ based on $\mathrm{E}(1 \%, 1 \mathrm{~cm})=11.7$ (Kinekawa and Kitabatake, 1995). Protein concentration of gelatins was measured by the BCA protein assay kit (Pierce Biotechnology, Rockford, IL) with BSA as a standard.

\section{Preparation of Sample for Astringency Evaluation}

The protein solution was adjusted $\mathrm{pH}$ to 3.5 with 2.0 $M \mathrm{HCl}$, and dialyzed against $5 \mathrm{~m} M$ sodium phosphate buffer, $\mathrm{pH}$ 3.5. The dialyzed protein solution was accurately adjusted $\mathrm{pH}$ to 3.5 with $5 \mathrm{~m} M$ sodium phosphate buffer, $\mathrm{pH}$ 3.5. The sample was diluted to a given protein concentration with $5 \mathrm{~m} M$ sodium phosphate buffer, $\mathrm{pH}$ 3.5, for evaluation of astringency.

\section{Evaluation of Astringency by the Threshold Method}

The astringency threshold was evaluated by sensory analysis. Three paper cups (A, B, and C) were prepared, and $5 \mathrm{~mL}$ of protein solution was put in one of the cups. The solvent ( $5 \mathrm{~m} M$ sodium phosphate buffer, $\mathrm{pH}$ 3.5) was placed in the other 2 cups. These 3 cups were given to the panel members, who were asked to indicate the cup that had the taste-eliciting solution. Next, similar experiments were done using the sample solution with higher protein concentration. By this method, the threshold values for taste sensation were obtained for each protein sample. Astringent strength was evaluated on a scale from 0 to 5 . A value of zero indicated that no taste was detected from the test solution and a value of 1 indicated that the sample solution elicited some taste stimulation. A value of 2 indicated the concentration at which the panel detected the astringent sensation in the sample solution. That is, the threshold value of astringent sensation is the concentration giving a value of 2 . Protein concentrations of samples were $0.125,0.25,0.50$, $1.0,1.5,2.0,2.5,3.0,4.0$, and $5.0 \mathrm{mg} / \mathrm{mL}$. The subjects were 7 healthy men ranging from 28 to $37 \mathrm{yr}$ old. First, subjects rinsed their mouths with distilled water and then tasted the sample solution. After tasting, subjects rinsed with $10 \mathrm{~m} M$ sodium phosphate buffer, $\mathrm{pH}$ 7.4, containing $150 \mathrm{mM} \mathrm{NaCl}$. Sample solution was kept at $23^{\circ} \mathrm{C}$ for $2 \mathrm{~h}$ before testing.

\section{Evaluation of Astringency by the Scalar Scoring Method}

Evaluation of astringency by the scalar scoring method was performed as follows. The subjects, preparation, and condition for tasting were the same as those described above. The sample volume was adjusted to 2.5 $\mathrm{mL}$ with $5 \mathrm{~m} M$ sodium phosphate buffer, $\mathrm{pH} 3.5$, and kept at $23^{\circ} \mathrm{C}$ for $2 \mathrm{~h}$ before testing. The astringency was standardized with tannic acid. Tannic acid solutions at $0,0.38,0.60,0.93,1.45$, and $2.26 \mathrm{~m} M$ were used as astringency standard solutions correlating with astringency scores of $0,2,4,6,8$, and 10 , respectively. The astringency of the protein sample was evaluated by astringency score compared with the astringency of standard tannic acid concentrations.

\section{Evaluation of Astringency by the Instrumental Method}

The astringency of the sample was evaluated using an instrumental method using a taste sensor (Taste Sensing System, SA402B; Intelligent Sensor Technology, Kanagawa, Japan). Change in the membrane potential caused by adsorption (CPA) was used to measure the astringency with SB2AE1 and SB2CN0 electrodes (Toukubo et al., 2000), and the astringency index of the sample was indicated as CPA value. The $5 \mathrm{~m} M$ sodium phosphate buffer, $\mathrm{pH} 3.5$, containing $0.3 \mathrm{mM}$ tartaric 


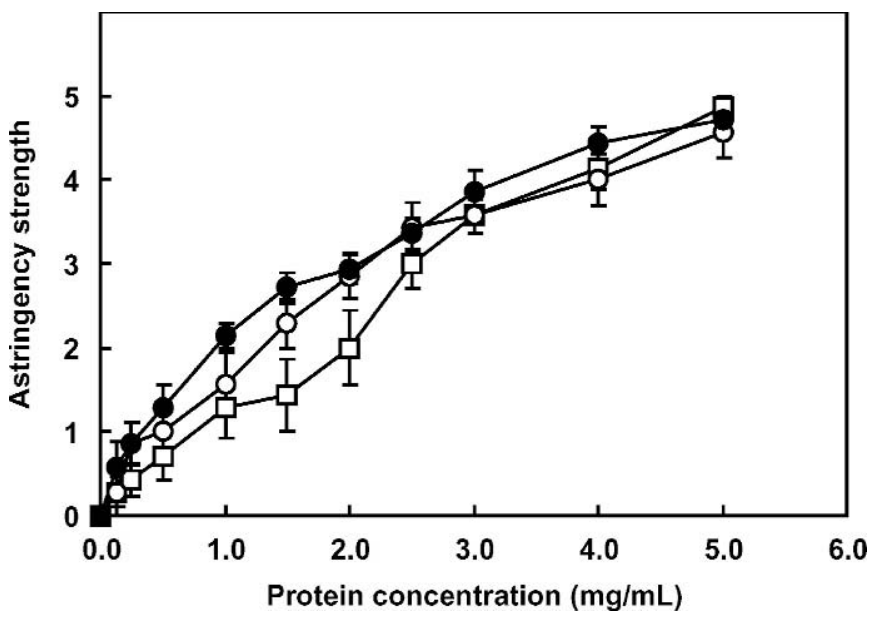

Figure 1. Astringency strength of whey protein isolate ( $\square$ ), process whey protein $(\mathrm{O})$, and acidic process whey protein $(-)$ at $\mathrm{pH} 3.5$ evaluated by threshold method of sensory analysis. Astringency strength values of $0,1,2,3,4$, and 5 indicate no taste, some taste elicited, slight astringent, astringent, strong astringent, and very strong astringent, respectively. Bars indicate the standard error $(\mathrm{n}=7)$.

acid and $30 \mathrm{~m} M$ potassium chloride, was used for preparation of the sample. This solution is recommended by the manufacturer of the taste sensor to stabilize the sensor probe. The composition of this solution imitates that of saliva. Analysis was done in triplicate, and the average values calculated were used.

\section{Statistical Analyses}

The statistical analyses were performed using Microsoft Excel 9.0 Analysis ToolPak (GreyMatter International Inc., Cambridge, MA). The significant difference of astringency data evaluated by the threshold, scalar scoring, and instrumental methods was analyzed using the 1-way or the replicated 2-way ANOVA. To analyze significant difference among astringency of sample proteins at various protein concentrations, the replicated 2-way ANOVA was used.

\section{RESULTS}

\section{Evaluation of Astringency by the Threshold Method}

The medium of protein solution ( $5 \mathrm{~m} M$ sodium phosphate buffer) elicited no astringency. The astringency of WPI, PWP, and aPWP solutions at $\mathrm{pH} 3.5$ increased with increasing protein concentration, which was evaluated by the threshold method of sensory analysis as shown in Figure 1. Astringency strength values were higher than 2 at above $2.0 \mathrm{mg} / \mathrm{mL}$, meaning that WPI, $\mathrm{PWP}$, and aPWP elicited astringency at above $2.0 \mathrm{mg} /$

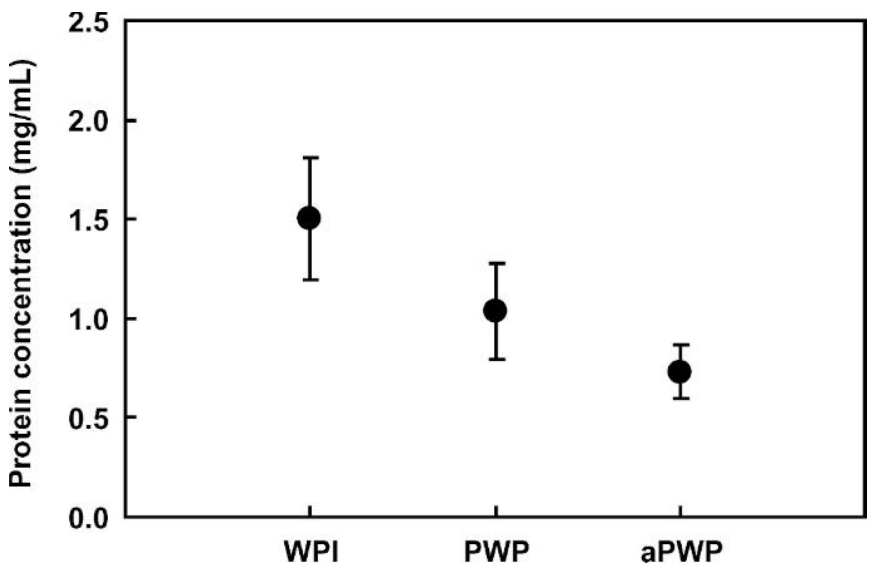

Figure 2. Threshold value of astringency of whey protein isolate (WPI), process whey protein (PWP), and acidic process whey protein (aPWP) at $\mathrm{pH} 3.5$ evaluated by sensory analysis. Bars mean standard error $(\mathrm{n}=7)$. No significant difference $(P>0.05)$ was observed among astringency threshold values of WPI, PWP, and aPWP.

$\mathrm{mL}$ of protein concentration. From Figure 1, the threshold value of astringency, that is, the protein concentration giving value 2.0 of astringency strength can be obtained. The threshold values of WPI, PWP, and aPWP are shown in Figure 2. The astringency thresholds of WPI, PWP, and aPWP at $\mathrm{pH} 3.5$ were $1.5,1.0$, and 0.7 $\mathrm{mg} / \mathrm{mL}$, respectively. A significance test was performed using the one-way ANOVA. No significant difference ( $P$ $>0.05$ ) was shown among astringency threshold values of WPI, PWP, and aPWP. Whey proteins are soluble globular proteins, whereas the solubility of these proteins is reduced at around $\mathrm{pH} 5$ (isoelectric precipitation).

As a control, we selected gelatin that is soluble in the range from acid to neutral $\mathrm{pH}$, and it is known that gelatin does not elicit astringency at acid $\mathrm{pH}$. Figure 3 shows the astringency of the gelatins from bovine and porcine skin. Astringency strength values of gelatin solutions from both bovine and porcine skin were less than 2.0 when protein concentration was lower than $2.5 \mathrm{mg} /$ $\mathrm{mL}$, indicating that neither gelatin was astringent. However, both gelatin solutions gave astringent strength values of 2.0 or higher when gelatin concentration was higher than $3.0 \mathrm{mg} / \mathrm{mL}$, indicating that gelatin showed slight astringency at high concentration at $\mathrm{pH}$ 3.5. It is not known whether this taste stimulation by the gelatin was caused by the gelatin molecule itself used in the present study or by some compound contaminating the gelatin sample. More investigation is needed to clarify this effect.

\section{Evaluation of Astringency by the Scalar Scoring Method}

Tannic acid was used as a standard compound for evaluation of the astringency by the scalar scoring 


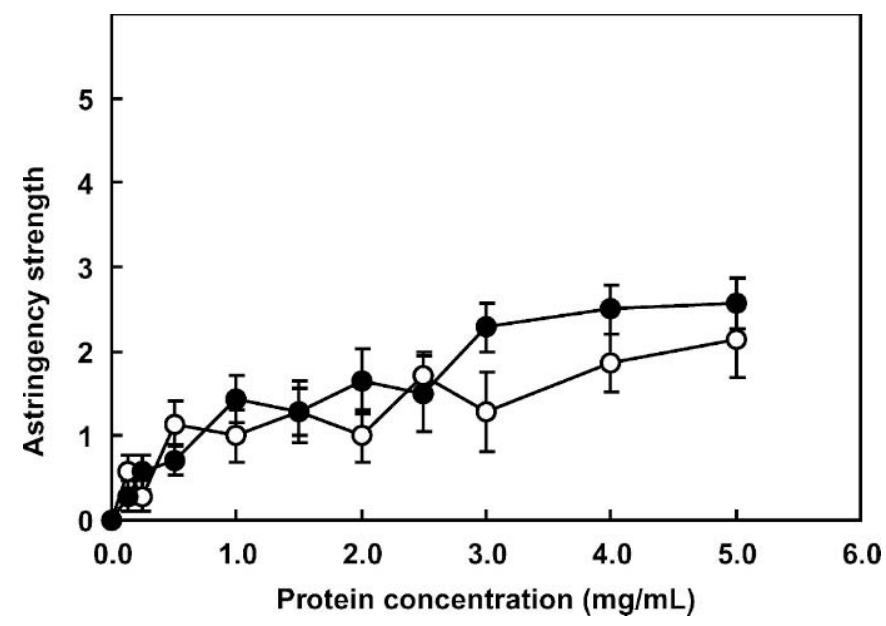

Figure 3. Astringency strength of gelatin from bovine skin $(\bigcirc)$ and porcine skin $(0)$ at $\mathrm{pH} 3.5$ evaluated by the threshold method of sensory analysis. Astringency strength values of $0,1,2,3,4$, and 5 indicate no taste, some taste elicited, slight astringent, astringent, strong astringent, and very strong astringent, respectively. Bars indicate standard error $(\mathrm{n}=7)$.

method. Concentrations of $0,0.38,0.60,0.93,1.45$, and $2.26 \mathrm{~m} M$ of tannic acid corresponded to astringency values of $0,2,4,6,8$, and 10, respectively. Relationship between astringency score and tannic acid concentration is shown in Figure 4. The correlation coefficient of fitting correlation line was 0.86 . Statistical significance of the correlation coefficient was confirmed $(P<0.01)$. From the correlation line, the astringency score is shown as follows.

\section{Astringency score $=$}

$4.50 \ln ($ tannic acid concentration $)+6.32$

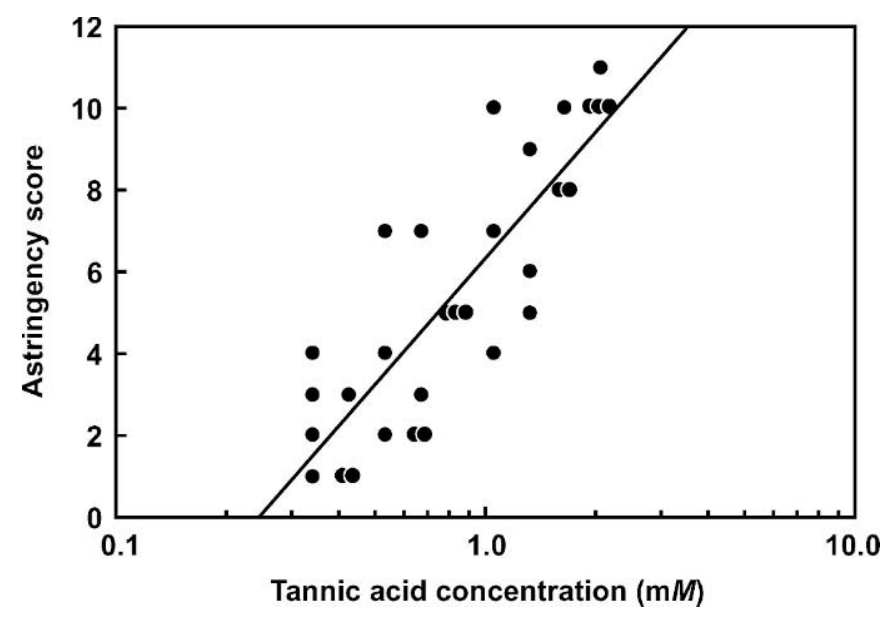

Figure 4. Relationship between astringency score and tannic acid concentration. A panel gave each scoring score for 6 samples containing 0.34 to $2.07 \mathrm{~m} M$ tannic acid $(\mathrm{n}=5)$.

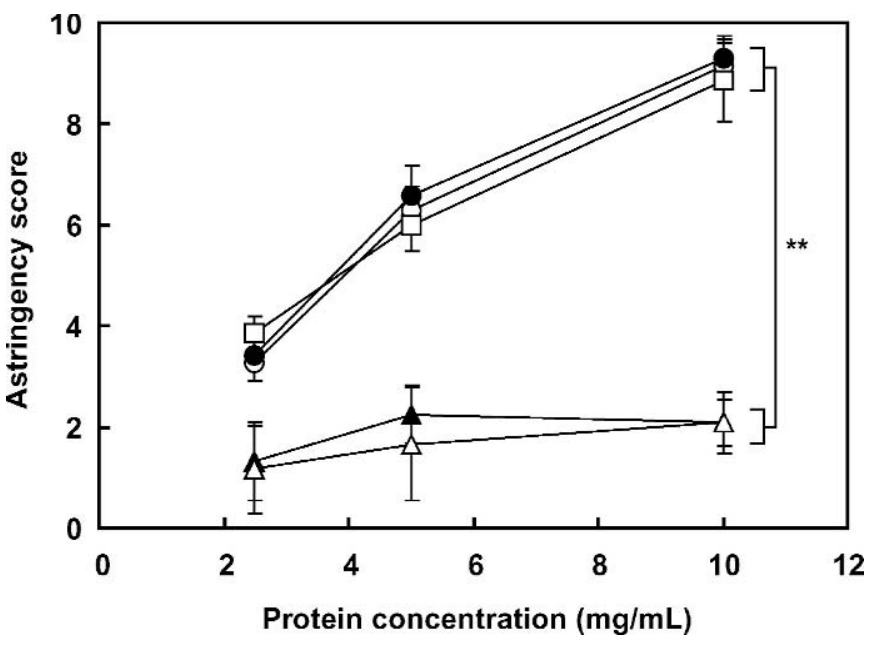

Figure 5. Astringency scores of whey protein isolate $(\square)$, process whey protein $(\bigcirc)$, acidic process whey protein $(\bullet)$, gelatin from bovine skin $(\triangle)$, and gelatin from porcine skin $(\boldsymbol{\Delta})$ at $\mathrm{pH} 3.5$ evaluated by scalar scoring method. Bars indicate standard error $(n=7)$. Significant difference was observed between 3 types of whey protein and 2 types of gelatin. $* * P<0.01$.

Figure 5 shows the astringency scores of WPI, PWP, and aPWP at $\mathrm{pH}$ 3.5. The astringency scores of WPI, $\mathrm{PWP}$, and aPWP increased with an increase in protein concentration; and no difference of astringency was observed among these whey proteins. The astringency scores of gelatin from bovine and porcine skin were less than 3 and not dependent on protein concentration up to $10 \mathrm{mg} / \mathrm{mL}$. Replicated 2-way ANOVA on WPI, PWP, and $\mathrm{aPWP}$ at $2.5,5.0$, and $10.0 \mathrm{mg} / \mathrm{mL}$ of protein concentration was performed. No significant difference $(P>$ 0.05) was shown among WPI, PWP, and aPWP at all protein concentrations, and no significant differences $(P$ $>0.05$ ) in both types of gelatin at all protein concentrations were observed. In addition, a significant difference was observed between whey proteins and gelatins $(P$ $<0.01$ ).

\section{Evaluation of Astringency by the Instrumental Method}

The whey protein and gelatin solution at $\mathrm{pH} 3.5$ were applied to a taste sensor equipped with an SB2CN0 electrode as a sensor probe. In the protein concentration range from 0.1 to $10 \mathrm{mg} / \mathrm{mL}$, CPA values of WPI, PWP, and aPWP increased with increasing protein concentration as shown in Figure 6. On the contrary, the gelatin solution with the same concentration as those of the whey proteins showed low CPA values. A significant difference was shown between whey proteins and gelatins $(P<0.01)$, and among WPI, PWP, and aPWP $(P<$ 0.01 ) at all protein concentrations, whereas no signifi- 


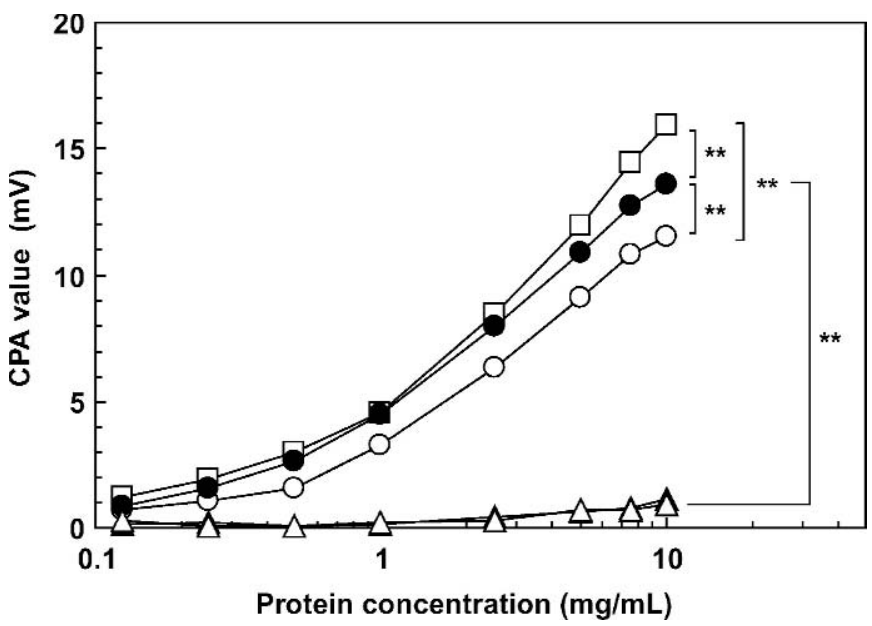

Figure 6. Change in the membrane potential caused by adsorption (CPA) values of whey protein isolate $(\square)$, process whey protein $(\bigcirc)$, acidic process whey protein $(\bullet)$, gelatin from bovine skin $(\triangle)$, and gelatin from porcine skin $(\mathbf{\Lambda})$ at $\mathrm{pH} 3.5$ measured by taste sensor instrument (with the SB2CN0 lipid membrane electrode). Significant differences were observed between 3 types of whey protein and 2 types of gelatin, and among 3 types of whey protein. ${ }^{* *} P<0.01$.

cant difference $(P>0.05)$ in both types of gelatin was obtained.

These observations correspond to those obtained by sensory analysis. The CPA values of WPI, PWP, and aPWP were plotted against the astringency scores obtained by sensory analysis (Figure 7). Correlation coefficients of WPI, PWP, and aPWP between CPA values

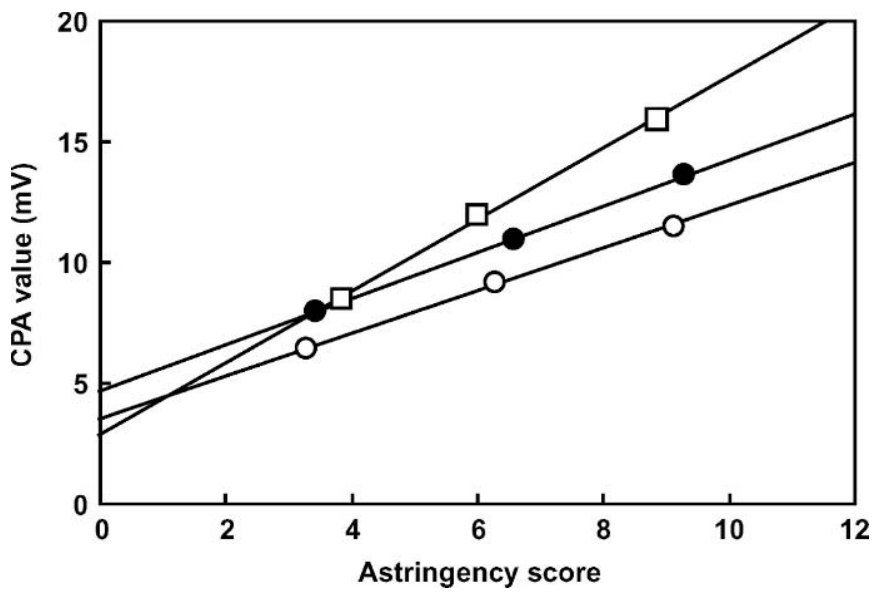

Figure 7. Relationship between astringency score of whey protein isolate $(\square)$, process whey protein $(\bigcirc)$, and acidic process whey protein (-) measured by sensory analysis, and change in the membrane potential caused by adsorption (CPA) of these proteins measured by the taste sensor instrument. The CPA values of 2.5, 5.0, and 10.0 $\mathrm{mg} / \mathrm{mL}$ whey protein isolate, process whey protein, and acidic process whey protein were plotted against astringency scores of these proteins, which were obtained by the scalar scoring method of sensory analysis. and astringency score were $0.9986(P=0.034), 0.9996$ $(P=0.018)$, and $0.9998(P=0.013)$, respectively. This indicates that the astringency of protein under acidic conditions can be evaluated by taste sensor using the SB2CN0 electrode. The SB2CN0 electrode was constructed from negatively charged lipid membrane. Under acidic conditions, whey proteins are positively charged, and protein molecules interact with the charged lipid membrane of the taste sensor by electrostatic force and hydrophobic interaction, which were detected by the sensor. However, when the SB2AE1 electrode (constructed from positively charged lipid membrane) was used, no response was detected for whey protein samples. Selection of an adequate electrode should be selected for obtaining reliable results, because not all electrodes would be useful for measurement of astringency of acidic protein solutions.

\section{DISCUSSION}

In the present study, we demonstrated that WPI, PWP, and aPWP solutions ( $\mathrm{pH}$ 3.5) elicited strong astringency in the mouth. Whey protein was dissolved in 5 $\mathrm{m} M$ sodium phosphate buffer, $\mathrm{pH}$ 3.5. The buffer did not elicit any astringency, and only whey protein dissolved in this buffer showed astringency, indicating that whey protein itself induced the astringent sensation. The WPI sample used in this study had high purity $(>95 \%)$, and the whey protein solution used in this study was dialyzed against distilled water or phosphate buffer exhaustively before each sensory experiment. Therefore, whey protein induced the astringent sensation. $\beta$-Lactoglobulin would be major component contributing to astringency.

Wine, green tea, and some fruits are known as foods that elicit astringent taste. The astringency of these foods is mostly caused by polyphenols contained in these foods (Horne et al., 2002). It is known that polyphenolic compounds interact with salivary protein to form a complex that precipitates on the surface of oral cavity and induces the astringent sensation in the mouth in humans (Charlton et al., 2002). In the case of whey protein, most of the whey protein, including $\beta$-lactoglobulin, precipitates at around pH 5 (Kitabatake et al., 1994). When acidic WPI solution ( $\mathrm{pH}$ 3.5) is placed in the oral cavity, the acidic solution is mixed with saliva ( $\mathrm{pH}$ is about 7), causing the $\mathrm{pH}$ of whey protein solution to increase and reach a $\mathrm{pH}$ of $\sim 5$. At this $\mathrm{pH}$, whey protein would precipitate in the mouth. This precipitate formed in the oral cavity would induce astringency in a similar way to the complex precipitation formed by salivary protein and polyphenolic compounds. Eliciting astringency from the whey protein under acidic conditions would occur in this way. 
Good correlation was observed between the CPA values measured by the instrumental method and the astringency score measured by sensory analysis in the case of WPI, PWP, and aPWP (see Figure 7). There was no correlation in the case of some other low molecular weight astringent compounds insofar as the same membrane was used (our unpublished data). Suitable membranes must be selected, depending on the types of astringent compounds and other protein samples. Further investigation is needed to clarify the relationship.

Process whey protein is prepared by heating WPI under salt-free conditions (Kinekawa and Kitabatake, 1995). The structure of molecule and aggregation of molecules in PWP is different from that of WPI, and PWP has unique and inherent functional properties as a food material, including gelation, emulsion, and viscosity, which are different from those of WPI. Process whey protein is the soluble aggregate of heat-denatured whey proteins, and PWP solution is clear in a wider $\mathrm{pH}$ range (from $\mathrm{pH} 4$ to 6) than WPI (Kitabatake et al., 1996; Kinekawa et al., 1998). However, there are no significant differences in astringency at $\mathrm{pH} 3.5$ among WPI, PWP, and aPWP when evaluated by the threshold method and the scalar scoring method. As these 3 types of whey protein precipitate at around $\mathrm{pH} 5$ without regard to molecular size, this precipitation would be related to astringent sensation.

If such astringency could be avoided from whey protein under acidic $\mathrm{pH}$ conditions, novel types of sour protein beverage could be prepared that would be acceptable to consumers.

\section{CONCLUSIONS}

Whey protein isolate, PWP, and aPWP elicited astringency at $\mathrm{pH} 3.5$, observed by the threshold method, the scalar scoring method, and the instrumental method. The astringency threshold value of WPI, PWP, and aPWP was $1.5,1.0$, and $0.7 \mathrm{mg} / \mathrm{mL}$, respectively. The astringency of these proteins at $2.5,5.0$, and $10 \mathrm{mg} / \mathrm{mL}$ of protein concentration was investigated by the scalar scoring method, and the astringency depended on protein concentration. The astringent intensity was not significantly different among WPI, PWP, and aPWP $(P>$
0.05). On the other hand, gelatin from bovine and porcine skin did not elicit definite astringency at $\mathrm{pH}$ 3.5. These whey proteins at $\mathrm{pH} 3.5$ gave significant CPA values by the instrument method using the SB2CN0 electrode, and these values corresponded with astringency of the sample, although no response was observed when both gelatins were measured.

\section{ACKNOWLEDGMENTS}

This work was financially supported by the Ministry of Agriculture, Forestry and Fisheries of Japan. We thank the members of Research \& Development Department of Daiichi-Kasei Co., Ltd. for sensory analysis.

\section{REFERENCES}

Alting, A. C., M. Weijers, E. H. A. de Hoog, A. M. van de Pijpekamp, M. A. C. Stuart, R. J. Hamer, C. G. de Kruif, and R. W. Visschers. 2004. Acid-induced cold gelation of globular proteins: Effects of protein aggregate characteristics and disulfide bonding on rheological properties. J. Agric. Food Chem. 52:623-631.

Charlton, A. J., N. J. Baxter, M. L. Khan, A. J. G. Moir, E. Haslam, A. P. Davies, and M. P. Williamson. 2002. Polyphenol/peptide binding and precipitation. J. Agric. Food Chem. 50:1593-1601.

Hansen, A. P., and J. J. Heinis. 1992. Benzaldehyde, citral, and $d$ limonene flavor perception in the presence of casein and whey proteins. J. Dairy Sci. 75:1211-1215.

Horne, J., J. Hayes, and H. T. Lawless. 2002. Turbidity as a measure of salivary protein reactions with astringent substances. Chem. Senses 27:653-659.

Kaneko, R., and N. Kitabatake. 2001. Structure-sweetness relationship in thaumatin: Importance of lysine residues. Chem. Senses 26:167-177.

Kinekawa, Y., T. Fuyuki, and N. Kitabatake. 1998. Effects of salts on the properties of sols and gels prepared from whey protein isolate and process whey protein. J. Dairy Sci. 81:1532-1544.

Kinekawa, Y., and N. Kitabatake. 1995. Turbidity and rheological properties of gels and sols prepared by heating process whey protein. Biosci. Biotechnol. Biochem. 59:834-840.

Kitabatake, N., E. Doi, and Y. Kinekawa. 1994. Simple and rapid method for measuring turbidity in gels and sols from milk whey protein. J. Food Sci. 59:769-772.

Kitabatake, N., Y. Fujita, and Y. Kinekawa. 1996. Viscous sol and gel formation from process whey protein below $25^{\circ} \mathrm{C}$. J. Food Sci. 61:500-503.

Kitabatake, N., and Y. Kinekawa. 1998. Digestibility of bovine milk whey protein and $\beta$-lactoglobulin in vitro and in vivo. J. Agric. Food Chem. 46:4917-4923.

Mulvihill, D. M. 1992. Production, functional properties and utilization of milk protein products. Adv. Dairy Chem. 1:369-404.

Toukubo, R., K. Sato, H. Ikezaki, A. Taniguchi, and K. Toko. 2000. Evaluation of the strength of astringency using multichannel taste sensor. Jpn. J. Taste Smell Res. 7:361-364. (in Japanese) 